\title{
THE DISTRIBUTION OF RADIOIODIDE IN THE GENITAL TRACT OF THE EWE
}

\author{
G. J. R. HOVELL, R. GULLEN AND K. BROWN-GRANT \\ The University Laboratory of Physiology, Oxford, \\ Wellcome Veterinary Research Station, Frant, Tunbridge Wells, Kent, and \\ MRC Neuroendocrinology Unit, Department of Human Anatomy, Oxford
}

(Received 2nd March 1973)

The infusion of solutions of iodine into the uterus through the cervical canal has been practised as a therapeutic measure in certain cases of infertility in farm animals. Little is known about the possible mode of action of such treatment, though Ekman, Holmberg, Settergren \& Thorell (1965) have shown that iodide is rapidly absorbed from the uterine lumen in the cow and have suggested that systemic as well as local effects might be involved. On the other hand, iodide has been shown to be present in the cervical mucus in women at a concentration above that in plasma (see Brown-Grant, 1961, for references) and in the rat, a very high concentration of iodide relative to plasma has been demonstrated in the oviduct and in the luminal epithelium of the uterus under certain conditions (Brown-Grant \& Rogers, 1972). A demonstration that iodide was selectively concentrated in some portion of the genital tract of the ewe would strengthen the case for a possible local action of infused iodide solutions and we have looked for evidence of any such concentration.

The animals were 5- to 8-year-old ewes of the Clun breed and were at pasture throughout, receiving only hay as a supplement to the diet and water. The first experiments were carried out during the 1971-72 breeding season in the period from November 1971 to January 1972. Vasectomized rams fitted with raddle harness had access to the ewes which were examined once or twice daily for colour marks. The day on which behavioural oestrus was first detected was taken as Day 0 of the cycle; experiments were performed on animals at different stages of the cycle as shown in Table 1. The ovaries of all animals were examined macroscopically at autopsy to check that ovarian appearance was consistent with the assigned stage of the cycle; one animal, thought to be at Day 9 of the cycle but without $\mathrm{CL}$ in the ovaries at autopsy, was excluded from the series. The experimental procedure involved the intramuscular injection of $100 \mu \mathrm{Ci}$ carrierfree $\mathrm{Na}^{131} \mathrm{I}$ (Radiochemical Centre, Amersham) in a volume of $1 \mathrm{ml}$. Two blood samples $(0.5 \mathrm{ml})$ were taken 120 min later and the animals were then killed by the intravenous injection of sodium pentobarbitone. Duplicate samples of the tissues to be studied ( 400 to $750 \mathrm{mg}$ ) were collected as quickly as possible and never more than 15 min after killing. Samples of cervical mucus were obtained on weighed swabs after opening the cervical canal, care being taken to avoid any contamination with urine. The ${ }^{131} \mathrm{I}$ content of blood and tissue samples was measured in an automatic gamma counter to a statistical accuracy of $\pm 2 \%$ 
or better. The tissue-blood (T/B) ratio (ct $/ \mathrm{min} / \mathrm{g}$ tissue divided by $\mathrm{ct} / \mathrm{min} / \mathrm{ml}$ blood) was calculated for each tissue sample and the mean of the duplicate values for the $\mathrm{T} / \mathrm{B}$ ratio was recorded.

The results from ten ewes killed at different stages of the cycle are shown in Table 1. Apart from the thyroid gland, the only samples for which a T/B ratio greater than unity was consistently obtained were the samples of cervical mucus and the mucosa of the cervical canal. There was a tendency for samples of these tissues collected around Day 0 of the cycle to have higher $\mathrm{T} / \mathrm{B}$ ratios than that

Table 1. Tissue/blood concentration ratios for ${ }^{131} I$ in tissues obtained from ewes killed at different stages of the oestrous cycle or during anoestrus

\begin{tabular}{l|c|c|c|c|c|c}
\hline $\begin{array}{c}\text { Stage of cycle } \\
\text { (no. of ewes) }\end{array}$ & Endometrium & Myometrium & $\begin{array}{c}\text { Cervical } \\
\text { mucosa }\end{array}$ & $\begin{array}{c}\text { Cervical } \\
\text { mucus }\end{array}$ & Liver & $\begin{array}{c}\text { Thyroid } \\
\text { gland }\end{array}$ \\
\hline Day -1* (1) & 1.04 & 0.83 & 1.22 & 5.50 & 0.50 & 295 \\
Day 0 (1) & 1.01 & 1.12 & 1.35 & 2.82 & 0.49 & 354 \\
Day 0 (1) & 0.83 & 0.80 & 1.22 & 3.49 & 0.41 & 607 \\
Day 1 (1) & 0.91 & 0.92 & 3.57 & 20.30 & 0.44 & 417 \\
Day 2 (1) & 0.90 & 0.74 & 1.88 & 4.10 & 0.43 & 301 \\
Day 3 (1) & 0.92 & 0.70 & 1.98 & 3.97 & 0.44 & 333 \\
Day 4 (1) & 0.84 & 0.72 & 1.11 & 2.32 & 0.41 & 133 \\
Day 8 (1) & 0.76 & 0.75 & 1.18 & 1.79 & 0.36 & 199 \\
Day 9 (1) & 0.90 & 0.89 & 1.13 & 1.69 & 0.40 & 139 \\
Day 10 (1) & 0.75 & 0.73 & 1.44 & 2.54 & 0.29 & 127 \\
Anoestrous & $0.80 \pm 0.02 \dagger$ & $0.74 \pm 0.03$ & $0.99 \pm 0.05$ & $1.72 \pm 0.27$ & $0.38 \pm 0.01$ & $302 \pm 27$ \\
controls (6) & & & & & & \\
Pretreated with & & & & & & \\
NaClO4 and & & & & & & \\
killed in & & & & & & \\
anoestrus (6) & $0.81 \pm 0.02$ & $0.77 \pm 0.02$ & $0.91 \pm 0.02$ & $0.83 \pm 0.10$ & $0.37 \pm 0.01$ & $7 \pm 1$ \\
\hline
\end{tabular}

* Killed 16 days after the last recorded oestrus; the ovaries contained an old CL and a medium follicle.

+ Mean \pm S.E.M.

of samples obtained during the luteal phase, but too few animals were examined for us to be certain that this was not a chance finding. Thyroid-blood ratios for ${ }^{131}$ I were also highest in animals killed around oestrus, as would be expected from the work of Robertson \& Falconer (1961). Ovarian hormones appear to play some rôle in maintaining the relatively high $\mathrm{T} / \mathrm{B}$ ratios for cervical mucus and mucosa as the mean values for these ratios for the ten sheep killed during the breeding season were higher than the mean values for samples from six sheep killed during the anoestrous period; these differences were significant $(P<0.02$ and $P=0.002$ in the Mann-Whitney U-test).

The finding of $\mathrm{T} / \mathrm{B}$ ratios greater than unity for cervical mucus and mucosa suggested that preferential accumulation of iodide might be occurring. If this were so, then the administration of perchlorate, which is known to inhibit active iodide transport systems elsewhere in the body (Brown-Grant, 1961), would be expected to reduce these ratios. This possibility was examined in a second series of experiments on anoestrous ewes in the May to July 1972 period. In these experiments, no tests of behaviour were made and all the ovaries appeared to be quiescent at autopsy. Alternate animals received $\mathrm{NaC1O}_{4}(10$ $\mathrm{mg} / \mathrm{kg}$ body weight) by intramuscular injection at two sites 45 to $60 \mathrm{~min}$ before 
the injection of $\mathrm{Na}^{131} \mathrm{I}$ but otherwise the experimental procedure was the same as in the experiments carried out during the breeding season. The results are given as group means \pm S.E.M. for six control and six perchlorate-treated anoestrous ewes in Table 1 . The reductions in the $\mathrm{T} / \mathrm{B}$ ratios for the thyroid gland and for cervical mucus were significant in the Mann-Whitney U-test $(P<0.002$ and $P<0.05$, respectively) and the T/B ratio for mucosa from the cervical canal was also reduced though not significantly.

Our findings show that iodide is probably accumulated preferentially in the cervical mucus and the mucosa lining the cervical canal in the sheep but not in the endometrium. It would be of interest to determine whether abnormalities in this constituent of the cervical mucus are associated with infertility in this or other species.

We wish to thank Miss F. Sharp, Wellcome Veterinary Research Station, for her conscientious technical assistance in these experiments.

\section{REFERENCES}

Brown-Grant, K. (1961) Extrathyroidal iodide concentrating mechanisms. Physiol. Rev. 41, 189.

Brown-Grant, K. \& Rogers, A. W. (1972) The sites of iodide concentration in the oviduct and the uterus of the rat. 7 . Endocr. 53, 355.

Ekman, L., Holmberg, O., Settrergren, I. \& Thorell, C. B. (1965) Resorption of iodine in Lugol's solution and in an iodophor from the uterus of cows. Nord. VetMed. 17, 391.

Robertson, H. A. \& Falconer, I. R. (1961) Reproduction and thyroid activity. F. Endocr. 22, 133. 